\title{
Factors Affecting Participation in Population-Based Mammography Screening
}

\author{
Topluma Dayalı Mamografi Taramasına Katılımı Etkileyen Faktörler \\ Iş1 MARAL, ${ }^{2}$ Iş1 İREM BUDAKOĞLU, ${ }^{1}$ Ayşegül ÖZDEMIR, ${ }^{3}$ Mehmet Ali BUMİN ${ }^{2}$ \\ Departments of ${ }^{1}$ Medical Education, ${ }^{2}$ Public Health, ${ }^{3}$ Radiology, Medical Faculty of Gazi University, Ankara
}

Submitted / Başvuru tarihi: 08.10.2008 Accepted / Kabul tarihi: 18.11.2008

\begin{abstract}
Objectives: This study aims to investigate the demographic or risk factors affecting participation in a population-based breast screening with mammography program in a rural area of Turkey.

Patients and Methods: This definitive epidemiological study was carried out between December 2002 and August 2003, in a town of Ankara. Of the 784 women, 710 were interviewed and 462 $(58.9 \%)$ of them participated in the screening. A questionnaire was used for collecting data.
\end{abstract}

Results: The mean age of the women was $50.7 \pm 10.0$ years. Fifty four percent of the single, widowed or divorced women ( $p=0.001), 62.5 \%$ of those aged 60 years or older $(p<0.001)$, and $42.8 \%$ of the illiterate or literate women $(p<0.001)$ did not participate the screening. Women, who were elder had a 1.1-fold greater risk of nonparticipation in mammography screening than younger ones (95\% confidence interval, 1.04-1.09), and those who were postmenopausal had 1.5-fold greater risk than those who were premenopausal (95\% confidence interval, 1.04-2.22).

Conclusion: Age, marital, educational and menopausal statuses seem to be effective on participation in the population-based study. Screening programs should be planned considering these factors.

Key words: Screening; mammography; populationbased; participation.
Amaç: Bu çalışmanın amacı Türkiye'nin kırsal bir alanında topluma dayalı mamografi taramasına katıımı etkileyen demografik ve risk faktörlerini incelemektir.

Hastalar ve Yöntemler: Tanımlayıcı epidemiyolojik çalışma olarak tasarlanan araştırmanın veri toplanması Aralık 2002 ve Ağustos 2003 tarihleri arasında Ankara'nın bir ilçesinde yapıldı. Toplam 784 kadından 710'u ile görüşüldü ve 462'si (\%58.9) taramaya katıldı. Veri toplamak için anket formu kullanıldı.

Bulgular: Kadınların ortalama yaşı $50.7 \pm 10.0$ yıldı. Bekar dul veya boşanmış olanların \%54'ünün $(p=0.0001), 60$ yaş ve üzerindekilerin \%62.5'inin $(p<0.001)$ ve okuma yazma bilmeyen veya okur yazar olanların \%42.8'inin $(p<0.001)$ taramaya katılmadığı saptandı. Yaşlı kadınların gençlere göre mamografi taramasına katılmama riskinin 1.1 kat (1.04-1.09; \%95 güven aralığı) ve menopoz sonrası dönemde olanların menopoz öncesi dönemde olanlara göre 1.5 kat (1.04-2.22; \%95 güven aralığı) daha fazla olduğu belirlendi.

Sonuç: Topluma dayalı meme kanseri taramasına katıımı etkileyen faktörler yaş, medeni durum, eğitim durumu ve menopozda olup olmamadır. Tarama planlanırken katıımı az olabilecek grupların katıımını artıracak uygulamaların geliştirilmesi önerilmektedir.

Anahtar sözcükler: Tarama; mamografi; topluma dayalı; katlım.

Presented at the 4th International Congress of Reproductive Health and Family Planning, April 20-23, 2005, Ankara, Turkey (4. Uluslararası Ureme Sağlığı ve Aile Planlaması Kongresi'nde sunulmuştur, 20-23 Nisan 2005, Ankara).

Correspondence (İletişim adresi): Dr. Işıl Irem Budakoğlu. Gazi Üniversitesi Tıp Fakültesi Tıp Eğitimi Anabilim Dalı, 06500 Ankara.

Tel: 0312 - 2027445 Fax (Faks): 0312 - 2024710 e-mail (e-posta): isiliremb@gmail.com

(c) Trakya Üniversitesi Tıp Fakültesi Dergisi. Ekin Tıbbi Yayıncıık tarafından basılımışır. Her hakkı sakıdır.

(c) Medical Journal of Trakya University. Published by Ekin Medical Publishing. All rights reserved. 
Despite varying health problems in different countries, breast cancer remains the most frequently encountered cancer among women globally. ${ }^{[1-3]}$ Mortality rates for breast cancer have consistently increased globally. ${ }^{[4]}$ Breast cancer ranks third among cancer deaths, with a calculated rate of 16.06 per 100000 in the European Union (EU). ${ }^{[5]}$ In Turkey, one in every four cancers detected in women was breast cancer and it comprises $1.3 \%$ of total disability-adjusted life years (DALY) at national level. ${ }^{[6]}$ In 2004, $1.6 \%$ of deaths in women aged 40 years or over was due to breast cancer. ${ }^{[7]}$

In 2001, the Republic of Turkey, Ministry of Health initiated the Breast Cancer Control Program. Early cancer diagnosis and screening centers were established in 29 cities. In addition, cancer screening and education centers were founded in 11 cities in a project implemented with the EU.

The best thing to control breast cancer is to diagnose it early. Regular mammography is an important part of preventive care. ${ }^{[8]}$ Although American Cancer Society (ACS) and United States Preventive Services Task Force (USPSTF) recommend that women at average risk should begin annual mammography screening at the age of 40 with $\mathrm{CBE},{ }^{[9,10]}$ the Canadian Task Force on Preventive Health Care (CTFPHC), the American Academy of Family Physicians (AAFP), and the American College of Preventive Medicine (ACPM) recommend beginning mammography for average-risk women at the age of 50. ${ }^{[10]}$ However, owing to its costs, mammography scanning could not be performed in all women older than 40 years in every country. Therefore, in countries with limited resources, different methods have been suggested for diagnosing breast cancer early. ${ }^{[11]}$ One of these methods is a screening program which is based on institutional or small regional areas. ${ }^{[11]}$ In Turkey, there are no studies on community-based mammography screening. However, such studies will be helpful in understanding the factors that affect participation in the community; they also can contribute to social awareness and create a favorable base from which to plan screening programs with a wider scope.

The purpose of the current study was to determine the factors affecting participation in mammography screening, contribute to planning an infrastructure required for community screenings.

\section{PATIENTS AND METHODS}

\section{Study Population and Setting}

Data collection of the study was carried out between December 2002 and August 2003. The study area was a district in the town of Gölbaşı, $20 \mathrm{~km}$ from Ankara, Turkey. A total of 784 women aged 40 years and over were living in this district. From these 784 women, 710 were interviewed and $462(58.9 \%)$ of them participated in the screening. The reason for selecting this district was that it was close to the Gazi University's Gölbaşı Campus where the investigators worked, and the district was in a central area and was easily accessible.

\section{Design}

The lists of this descriptive study were obtained from the records of the primary care health institution. The women 40 years and over were later visited at their homes in order to get their phone numbers. Then, the survey form that had been designed to assess their sociodemographic and fertility characteristics, breast cancer symptoms, and knowledge levels regarding early diagnosis methods was administered while visiting at home. Following these procedures, screening was continued by calling 15 to 20 women every day; those who agreed to participate were asked to come to the campus the next day. The women were brought for a mammography to the radiology department with minibuses in groups of 10 to 15 and sent back to their homes with the same minibuses after the mammography. All stages of screening were free of payment and it was financed by the Gazi University under a grant from Gazi University Scientific Investigation Projects, Project Code No. 01/2003-07. Prior to the screening, the women were informed about the mammography procedure and the transportation. Approval of the local ethics committee (Gazi University No.01/2003-07) and written informed consent of all participants were obtained.

\section{Analysis}

The study data were analyzed with SPSS software (Statistical Package for the Social Sciences, version 11.0, SSPS Inc, Chicago, Ill, USA). The descriptive dichotomous data were evaluated as numbers and percentages and the continuous data as the mean and standard error of mean. Bivariate analyses were used to examine changes between dependent and independent variables using the Student's t-test and Chi-square test for statistical dependence. A multivariate analysis (logistic regression) was then carried out to identify the relative influence of significant characteristics which was determined by bivariate analyses. A p value of less than .05 was considered statistically significant.

\section{RESULTS}

Seven hundred and ten of the women were interviewed, and $462(58.9 \%)$ participated in the screening program. Of the 248 women who did not participate, $159(64.5 \%)$ did not agree to participate in the study, $34(13.5 \%)$ did not answer at least three phone calls, 21 (8.2\%) were outside the investigation site during the training periods, the phone numbers of 32 subjects $(13.0 \%)$ were not available, and two subjects $(0.8 \%)$ died in the period between the survey interview and the screening. The first four excuses expressed by the 159 women who did not agree to participate in the screening were that 38 women $(24.1 \%)$ did not need such a thing, 23 women's 
Table 1. Distribution of the descriptive characteristics of the participants and nonparticipants, Ankara, 2003

\begin{tabular}{|c|c|c|c|c|c|c|c|}
\hline \multirow[t]{2}{*}{ Characteristics } & \multicolumn{2}{|c|}{ Participants } & \multicolumn{2}{|c|}{ Nonparticipants } & \multicolumn{2}{|c|}{ Total } & \multirow[t]{2}{*}{$p^{*}$} \\
\hline & $\mathrm{n}$ & $\% 0^{\mathrm{a}}$ & $\mathrm{n}$ & $\% \mathrm{a}$ & $\mathrm{n}$ & $\% \mathrm{~b}$ & \\
\hline \multicolumn{8}{|l|}{ Age groups } \\
\hline 59 years and lower & 411 & 71.6 & 163 & 28.4 & 574 & 80.8 & $<0.001$ \\
\hline 60 years and over & 51 & 37.5 & 85 & 62.5 & 136 & 19.2 & \\
\hline \multicolumn{8}{|l|}{ Marital status } \\
\hline Married & 410 & 68.7 & 187 & 31.3 & 597 & 84.1 & 0.0001 \\
\hline Single/widow/divorced & 52 & 46.0 & 61 & 54.0 & 113 & 15.9 & \\
\hline \multicolumn{8}{|l|}{ Education status } \\
\hline Illiterate or literate & 170 & 57.2 & 127 & 42.8 & 297 & 41.8 & $<0.001$ \\
\hline Primary school graduate or higher & 292 & 70.7 & 121 & 29.3 & 413 & 58.2 & \\
\hline \multicolumn{8}{|l|}{ Employment status } \\
\hline Housewife & 444 & 65.4 & 235 & 34.6 & 679 & 95.6 & 0.6962 \\
\hline Employed & 6 & 60.0 & 4 & 40.0 & 10 & 1.4 & \\
\hline Retired & 12 & 57.1 & 9 & 42.9 & 21 & 3.0 & \\
\hline \multicolumn{8}{|l|}{ Social security status } \\
\hline Present & 158 & 63.2 & 92 & 36.8 & 250 & 35.2 & 0.4913 \\
\hline Absent & 304 & 66.1 & 156 & 33.9 & 460 & 64.8 & \\
\hline \multicolumn{8}{|l|}{ Previous breast disease } \\
\hline Yes & 409 & 64.6 & 224 & 35.4 & 633 & 89.2 & 0.5442 \\
\hline No & 53 & 68.8 & 24 & 31.2 & 77 & 10.8 & \\
\hline \multicolumn{8}{|l|}{ Menopausal status } \\
\hline Pre- or perimenopausal & 270 & 74.2 & 94 & 25.8 & 364 & 51.3 & 0.0001 \\
\hline Postmenopausal & 192 & 55.5 & 154 & 44.5 & 346 & 48.7 & \\
\hline \multicolumn{8}{|l|}{ Having had a $\mathrm{MG}^{\mathrm{c}}$ at least once } \\
\hline Yes & 371 & 63.4 & 214 & 36.6 & 585 & 82.4 & 0.0583 \\
\hline No & 91 & 72.8 & 34 & 27.2 & 125 & 17.6 & \\
\hline \multicolumn{8}{|l|}{ Family breast cancer history } \\
\hline No & 417 & 64.3 & 232 & 35.7 & 649 & 91.5 & 0.1259 \\
\hline Yes & 45 & 75.0 & 15 & 25.0 & 60 & 8.5 & \\
\hline
\end{tabular}

${ }^{a}$ Row percentage; ${ }^{b}$ Column percentage; ${ }^{c}$ Mammography; ${ }^{*}$ Chi-square test.

$(14.6 \%)$ husbands did not allow to participate the screening, 15 women $(9.5 \%)$ had diseases other than the breast disease, and 13 women attended follow-ups at another center $(8.2 \%)$.

The average age of the interviewed women was $50.7 \pm 0.7$ years, and the median age was 48.0 years (range, 40-95 years); the average ages of the women who participated and not participated in the screening program was $48.5 \pm 0.4$ and $54.8 \pm 0.8$ years, respectively $(\mathrm{p}<0.001$, Student's t-test).

More than half of the women aged 60 years and over $(62.5 \%)$ did not participate in the screening, and this difference was statistically significant when compared with the other age group $(p<0.001)$. The marital and educational statuses of the women also affected participation in the screening. The percentage of married women who did not participated was lower than that of single and widowed/divorced women $(31.3 \%$ versus $54.0 \%)(p=0.0001)$. The number of non-participated women increased as their educational status became lower. The number of women in the "illiterate or literate" group that non-participated was statistically significantly higher than that of the other group $(42.8 \%$ versus $29.3 \%)(p<0.001)$ (Table 1$)$. There were no statistically significance between employment status and participation also social security and participation status $(\mathrm{p}>0.05)$ (Table 1).

The menopausal status of the women also affected participation in the screening program. The rate of participation by premenopausal women was statistically higher than pre- or perimenopausal ones $(p=0.0001)$ (Table 1). There were no statistically significance between previous breast disease, having had a mammography at least once and family breast cancer history and participation status $(\mathrm{p}>0.005)$ (Table 2$)$. The logistic regression analysis of the factors affecting participation in the screening program is presented in Table 2. 
Table 2. Multivariate (logistic regression) analysis of factors influencing participation in the screening program with a logistic regression analysis, Ankara, 2003

\begin{tabular}{|c|c|c|c|c|c|}
\hline Factors & & $\beta$ & OR & $95 \% \mathrm{CI}$ & $p$ \\
\hline Age & & 0.060 & 1.06 & 1.04-1.09 & $<0.001$ \\
\hline \multirow[t]{2}{*}{ Marital status } & Married/widow/divorced & & 1.00 & & \\
\hline & Never married & 0.945 & 2.57 & $0.36-18.51$ & 0.348 \\
\hline \multirow[t]{4}{*}{ Educational status } & Illiterate & & 1.00 & & \\
\hline & Literate & 0.104 & 1.11 & $0.54-2.28$ & 0.777 \\
\hline & Primary school graduate & 0.151 & 1.16 & $0.53-2.54$ & 0.705 \\
\hline & Secondary school or higher & 0.117 & 1.12 & $0.58-2.18$ & 0.728 \\
\hline \multirow[t]{2}{*}{ Menopausal status } & Pre- or perimenopausal & & 1.00 & & \\
\hline & Postmenopausal & 0.421 & 1.52 & $1.04-2.22$ & 0.029 \\
\hline \multirow[t]{2}{*}{ Previous mammography } & Yes & & 1.00 & & \\
\hline & No & 0.357 & 1.43 & $0.91-2.56$ & 0.126 \\
\hline
\end{tabular}

OR: Odds ratio; CI: Confidence interval

According to the evaluation of the factors affecting participation in the screening, elder women had a 1.06fold great risk of nonparticipation to mammography screening than younger (1.04-1.09; 95\% CI), and those who were postmenopausal had 1.5 -fold greater risk than those who were premenopausal $(1.04-2.22 ; 95 \% \mathrm{CI})$ (Table 2).

During screening, lesions were detected in the breasts of 116 women $(25.1 \%)$. The lesions were benign characteristics in $133(24.9 \%)$ cases according to mammography and ultrasonography examination while three $(0.6 \%)$ lesions had malignant. According to pathological examination, all these three malignant lesions were diagnosed as breast cancer.

\section{DISCUSSION}

This study is the first in our country to investigate the factors that can affect participation in a breast screening program. Among the limitations of the study were that the screening was performed in only one region, and the rate of the participation in the screening program was low $(58.9 \%)$.

Of the 248 nonparticipated women, 159 (64.5\%) did not agree to participate in the screening, and the most frequently cited excuse was that the women "did not need such a thing" (24.1\%). The women constituting the scope of the study were invited for the screening via a phone interview. During this interview, it was stated that the screening was a mammography scan for breast cancer; however, the potential benefits or harms of mammography could not be explained. The risk of the procedures to be performed and proof regarding a decrease in disease risk must be shared with persons in communitybased screening programs. However, the decision to participate in a health-related screening program will still be theirs, even when this information is shared. ${ }^{[12]}$ The recommendation of a physician plays a crucial role in participating in mammography screening; however, the participation rate is still low even if the primary care patient-physician relationship is very good. ${ }^{[13]}$

The percentage of participation was lower for women who were older, illiterate, and postmenopausal compared with the other groups $(\mathrm{p}<0.05)$. On logistic regression model analyses using these independent variables, elder women were found to be at a 1.06-fold great risk of nonparticipation to mammography screening than younger $(1.04-1.09 ; 95 \%$ CI). Those who were postmenopausal had 1.5 times the risk of women who were premenopausal (1.04-2.22; 95\% CI). It has been reported that women's knowledge about disease risk, their incomes, race, and relations with their primary care physicians, and their worries correlate with participation in mammography screening. ${ }^{[14]}$ The results of a community-based mammography screening program performed in Spain ${ }^{[15]}$ and Colorado ${ }^{[16]}$ showed that the possibility of not undergoing mammography was higher in elderly women, which is similar to our findings. A study performed in Sweden showed that married and more educated women had higher participation rates than single, widowed or divorced and lower educated women. ${ }^{[17]}$ Another study performed by Augustson et al. ${ }^{[18]}$ reported that women with at least a high school education were more likely to be adherent to mammography screening. Carney et al. ${ }^{[14]}$ reported that those with social security, women with cancer in their first-degree relatives, and those undergoing hormone replacement treatments participated in the screening more frequently than did women who did not have these characteristics. According to our results and the other studies listed above, age and educational status seem the most influential factors affecting participation in the mammography screening.

Breast cancer was detected in three women (6.5\%) in our study. The screening prevalence of breast can- 
cer reported between $2.7-7.6 \%$ in different studies. ${ }^{[19]}$ According to a study performed by Poplack et al., ${ }^{[20]}$ screening mammography detected malignancy in 3.3 per 1000 women. ${ }^{[20]}$ An organized mammography screening program from Canada reported the cancer detection rate as 6.9 per 1000 screens at first screen. ${ }^{[21]}$ Although our study group comprises a small population, the percentage of breast cancer detected with our screening program was similar with other studies.

In conclusion, we think that for community-based mammography screening, in order to realize the full benefits and use of national resources properly, targeting women who are elder, single, widowed or divorced, illiterate, and those who are postmenopausal will be most beneficial. The policy makers shall organize such screening programs, targeting the risk groups. Use of different motivation techniques can increase the effectiveness of and the participations in the screenings. However, further studies in larger groups that more elaborately investigate cause-and-effect relationships are needed.

\section{Acknowledgement}

We thank the mammography technicians of Radiology Department, and all the women who participated in this study.

\section{REFERENCES}

1. Henderson BE, Pike MC, Bernstein L, Ross RK. Breast cancer. In: Schottenfeld D, Fraumeni JF Jr, editors. Cancer epidemiology and prevention. 2nd ed. Oxford: Oxford University Press; 1996. p. 1022-40.

2. Trichopoulos D, Lipworth L, Petridou E, Adami HO. Epidemiology of cancer. In: DeVita VT, Hellman S, Rosenberg SA, editors. Cancer principles and practice of oncology. 5th ed. Philadelphia: Lippincott-Raven; 1997. p. 231-59.

3. IARC Handbooks of Cancer Prevention, Vol. 7: Breast cancer screening. Lyon: World Health Organization International Agency for Research on Cancer; 2002. p. 1-4.

4. The World Health Report 2003. Available from: http:// www.who.int/whr/2003/en/Annex3-en.pdf, accessed 4 March 2008.

5. European Community Commission Suggestion for a Council Recommendation on Cancer Screening 2003. Available from: http://www.saglik.gov.tr/extras/birimler / ksdb / ABkanser_tarama_tav_kar.doc, accessed 4 March 2008.

6. Burden of Disease Final Report. National Burden of Disease and Cost-Effectiveness Project. Ankara: The Ministry of Health of Turkey, Başkent University, School of Public Health; 2005. p. 581-8.

7. Death Statistics in the Province and Town Centers 2004.
Ankara: Republic of Turkey, Turkish Statistics Institute; 2006. p. 72-88.

8. Özdemir A. Imaging modalities and screening in breast cancer. Turkiye Klinikleri J Med Oncol-Special Topics 2008;1:5-10.

9. Smith RA, Saslow D, Sawyer KA, Burke W, Costanza ME, Evans WP 3rd, et al. American Cancer Society guidelines for breast cancer screening: update 2003. CA Cancer J Clin 2003;53:141-69.

10. Recommendations and Rationale Screening for Breast Cancer U.S. Preventive Services Task Force (USPSTF). Available from: http://www.ahrq.gov/clinic/3rduspstf/ breastCancer/brcanrr.htm, accessed 10 November 2008.

11. Anderson BO, Braun S, Lim S, Smith RA, Taplin S, Thomas DB; Global Summit Early Detection Panel. Early detection of breast cancer in countries with limited resources. Breast J 2003;9 Suppl 2:S51-9.

12. Ward J. Population-based mammographic screening: does 'informed choice' require any less than full disclosure to individuals of benefits, harms, limitations and consequences? Aust N Z J Public Health 1999;23:301-4.

13. Taplin SH, Barlow WE, Ludman E, MacLehos R, Meyer $\mathrm{DM}$, Seger $\mathrm{D}$, et al. Testing reminder and motivational telephone calls to increase screening mammography: a randomized study. J Natl Cancer Inst 2000;92:233-42.

14. Carney PA, Harwood BG, Weiss JE, Eliassen MS, Goodrich ME. Factors associated with interval adherence to mammography screening in a population-based sample of New Hampshire women. Cancer 2002;95:219-27.

15. Baré ML, Montes J, Florensa R, Sentís M, Donoso L. Factors related to non-participation in a population-based breast cancer screening programme. Eur J Cancer Prev 2003;12:487-94.

16. Crane LA, Leakey TA, Rimer BK, Wolfe P, Woodworth MA, Warnecke RB. Effectiveness of a telephone outcall intervention to promote screening mammography among low-income women. Prev Med 1998;27(5 Pt 2):S39-49.

17. Bulliard JL, De Landtsheer JP, Levi F. Reattendance in the Swiss mammography screening pilot programme. J Med Screen 2004;11:59-64

18. Augustson EM, Vadaparampil ST, Paltoo DN, Kidd LR, O'Malley AS. Association between CBE, FOBT, and Pap smear adherence and mammography adherence among older low-income women. Prev Med 2003;36:734-9.

19. Svane G, Potchen EJ, Sierra A, Azavedo E. Problems in breast cancer detection. In: Paterson A, editor. Screening mammography. St Louis: Mosby; 1993. p. 17-66.

20. Poplack SP, Tosteson AN, Grove MR, Wells WA, Carney PA. Mammography in 53,803 women from the New Hampshire mammography network. Radiology 2000;217:832-40.

21. Paquette D, Snider J, Bouchard F, Olivotto I, Bryant H, Decker K, et al. Performance of screening mammography in organized programs in Canada in 1996. The Database Management Subcommittee to the National Committee for the Canadian Breast Cancer Screening Initiative. CMAJ 2000;163:1133-8. 